\title{
Aeromonas infection from river and playa lake waters in West Texas and southeastern New Mexico
}

\author{
Robert C. Kimbrough MD, Richard E. Winn MD, Randall M. Jeter PhD, \\ William J. Warren PhD, Jennifer R. Huddleston PhD, John C. Zak PhD
}

\begin{abstract}
Trauma occurring in direct contact with freshwater bodies may result in wounds contaminated with a variety of microorganisms. Bacteria belonging to the genus Aeromonas have been recovered from these types of infections. We report two cases of Aeromonas hydrophila infections occurring from freshwater-contaminated wounds. One of these infections was acquired from a river in southeastern New Mexico; the other was from an urban playa lake in West Texas. The latter case prompted an ecological study of the seasonal occurrence of Aeromonas spp. and the incidence of resistance to antimicrobial agents in two of these local lakes. Recent scientific and medical literature data show that Aeromonas should be considered as a possible agent of infection in immunocompetent hosts from water exposure, even if the water is a running river or a seemingly unpolluted ("clean") freshwater lake.
\end{abstract}

Key words: Aeromonas, water borne infection, playa lakes

\section{INTRODUCTION}

Members of the bacterial genus Aeromonas are known to infect wounds that occur in contact with either polluted or unpolluted ("clean") freshwater. ${ }^{1-3}$ We report a scalp-wound infection and a unique bloodstream infection occurring in two patients exposed to freshwater sources in West Texas and southeastern New Mexico, respectively. Aeromonas infection in the former patient led to a year-long study of the seasonal occurrence and incidence of resistance to antimicrobial agents among Aeromonas isolates from two urban playa lakes within the city limits of Lubbock, TX. ${ }^{4}$

Corresponding author: Richard Winn, MD

Contact Information: Richard.winn@ttuhsc.edu DOI: 10.12746/swrccc2016.0416.215
In addition, we surveyed the recent (1998-2011) scientific and medical literature for reports of Aeromonas infections and summarize pertinent information.

\section{CASE REPORTS}

Case 1. A 32-year-old white woman sustained a blast injury and $60 \%$ body burn in a natural gas pipeline explosion while camping beside the Pecos River near Carlsbad, NM (Figure 1). She dove into the river to quench the fire. She was admitted to the burn ICU in critical condition. She was febrile at the time of admission and became septic. On the second day of hospitalization, her blood cultures grew Aeromonas hydrophila. Her wounds did not grow this organism, nor did bronchial washings. The large-line intravenous 
(IV) device, which was placed at the scene while she was still wet from the river, also grew $A$. hydrophila. She was treated with appropriate antibiotics, but died after 30 days due to burn trauma and inhalation injury.

Case 2. A 26-year-old Hispanic man lacerated his scalp while swimming in a local playa lake in Lubbock, TX (Figure 1). The wound was initially closed and subgaleal infections ensued. He developed massive facial and neck edema and required intubation. He required incision and drainage twice. A. hydrophila was recovered in pure culture. The patient was treated with appropriate antibiotics and discharged after 10 days of antibiotic therapy. He was followed for a one-year period with his face and scalp returning to normal.

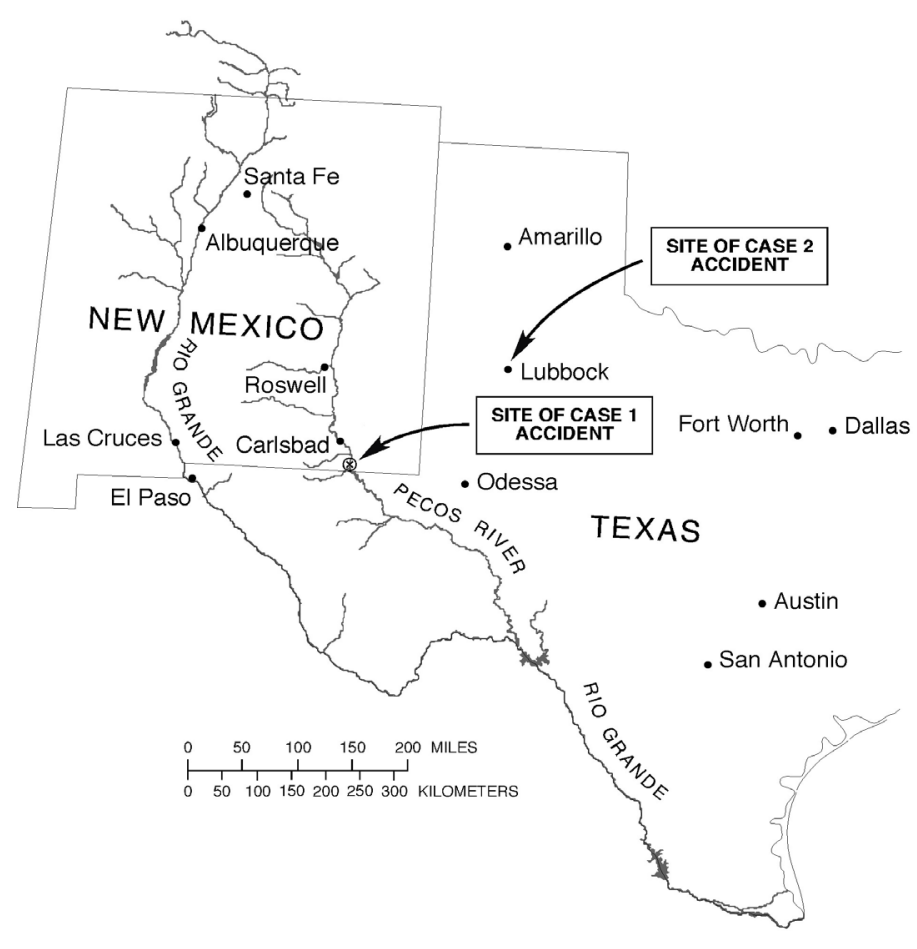

Figure 1. Geographical locations of the sites where the Aeromonas infections in these cases occurred

\section{MATERIALS AND METHODS}

All clinical specimens were collected by cotton-tipped swabs, suction catheters, or standard blood culture techniques. They were processed for species identification and antimicrobial sensitivities in the hospital clinical microbiology laboratory at Texas Tech University Health Sciences Center by using a replicator device of standard manufacture with reagents and equipment from the same company (Dade MicroScan ${ }^{\mathrm{TM}}$, Dade Behring, Inc., 1584 Enterprise Blvd., West Sacramento, CA 95691). The playa-lake study procedures have been described previously. ${ }^{4}$

\section{Pertinent literature ReView}

Genus definition. The genus Aeromonas consists of Gram-negative, rod-shaped bacteria that are generally motile by means of single polar flagella. They are facultative anaerobes. . $^{5,6}$

Organism distribution. Aeromonads are ubiquitous in aquatic environments and have been isolated from fresh and brackish water ${ }^{7,8}$, urban wastewater ${ }^{9}$, aquatic sediments ${ }^{4}$, and soils that have been recently irrigated or flooded. ${ }^{10}$ They have also been found in drinking water supplies, perhaps because they can form biofilms that are resistant to chlorination. ${ }^{11}$ Aeromonads have been detected in bottled natural mineral waters ${ }^{12}$ and in various foodstuffs, including raw fish and shellfish, poultry, meat products, milk, and fresh vegetables. ${ }^{13,14}$ Aeromonas is also found in association with a growing list of invertebrate and vertebrate animals, including molluscs (snails and mussels) ${ }^{15,16}$, annelids (leeches) ${ }^{17-19}$,crustaceans (shrimp) ${ }^{20}$, insects (mosquitoes) $^{21}$, fishes $^{22}$, amphibians (frogs) ${ }^{23}$, reptiles (snakes and crocodiles) ${ }^{24,25}$, birds $^{26}$, and mammals ${ }^{27}$. In some cases, the aeromonads form part of the host animal's normal microbial flora; in others, they act as invading parasites that can cause potentially lethal infections.

Disease associations. Aeromonas species cause diseases in several poikilothermic animals, including fish, frogs, and other amphibians (primarily 
A. hydrophila). ${ }^{28,29}$ Several Aeromonas species also act as pathogens in humans. ${ }^{30,31}$ Aeromonas hydrophila is the most frequently isolated species in cases of human infection. $A$. caviae and $A$. veronii biovar sobria are also commonly isolated..$^{32}$ Other less frequently isolated human pathogens are $\mathrm{A}$. veronii biovar veronii, $A$. jandaei, and $A$. schubertii. ${ }^{33}$ A single case of infection by $A$. popoffii has been reported. ${ }^{34}$

Traditionally Aeromonas has been described as an opportunistic pathogen, but more recent reports in the medical literature of Aeromonas infections in healthy, immunocompetent adults suggest that, in some cases, Aeromonas may be regarded as a primary pathogen as well. Gastroenteritis is the most commonly reported clinical illness associated with Aeromonas infection, which typically manifests as acute, watery diarrhea. ${ }^{35}$ Although this condition is usually self-limiting in otherwise healthy individuals, the symptoms can be more severe in children, the elderly, and immunocompromised patients. ${ }^{36-41}$ Severe cholera-like or dysenteric diarrheal diseases occur more rarely. ${ }^{32}$ The association between Aeromonas and diarrheal symptoms has recently been questioned. ${ }^{42}$ Aeromonas has also been recovered from fecal samples taken from healthy, asymptomatic individuals. The bowel carriage rate is generally considered to be about $3-5 \%$ in temperate regions ${ }^{43}$ but higher in tropical areas. One study found a carriage rate as high as $27 \%$ in a Thai population of 51 healthy adults. ${ }^{44}$ Thus, the human gastrointestinal tract may serve as a reservoir for potentially pathogenic Aeromonas strains. latrogenic Aeromonas infections have been associated with medicinal leech therapy due to a specific host-microbe symbiosis with $A$. veronii. ${ }^{18}$

Routes of infection. The principal routes by which Aeromonas enters the human body are the gastrointestinal tract (by ingestion of contaminated food or water) and wounds to the skin surface (cuts, scratches, punctures, and burns) from water exposure. The latter infections are usually selflimiting, but on occasion, entry of Aeromonas into the bloodstream can result in life-threatening septicemia. Other apparent routes of infection include the respiratory tract (inhalation leading to pneumonia or other types of pulmonary infections), urinary tract, and ocular infections. ${ }^{33}$ Aeromonas infections have also resulted from the treatment of surgical incisions with medicinal leeches, which appear to form a stable host-symbiont association with $A$. veronii in the leech digestive tract. ${ }^{45-47}$

Disease consequences. Wound (skin and soft-tissue) infections are the second most common type of infections caused by Aeromonas species. These infections are generally self-limiting in immunocompetent individuals but can become life-threatening if septicemia develops, especially in immunocompromised individuals. Among 305 survivors of the December 2004 tsunami in southern Thailand who were treated for skin and soft-tissue infections, 145 of 641 (22.6\%) bacterial isolates from the pus and/or wound cultures were identified as Aeromonas, including $104 \mathrm{~A}$. hydrophila and $41 \mathrm{~A}$. veronii biovar sobria. ${ }^{48}$

Antibiotic resistance. Many clinical isolates of Aeromonas have a high-level resistance to $\beta$-lactam antibiotics and first-generation cephalosporins in vitro. Unbiased surveys of both clinical and environmental strains typically show that the prevalence of ampicillin resistance is $70-90 \% .{ }^{49-51}$ Several different Aeromonas clinical isolates have been analyzed in detail and found to produce two or three chromosomally encoded $\beta$-lactamases with overlapping substrate specificities. $^{52,53}$ Occasionally, strains have also been isolated that carry plasmid-borne $\beta$-lactamase genes. ${ }^{52,54}$ Resistances to other antimicrobial drugs and antibiotics have been reported. For example, a recent study in India of $21 \mathrm{~A}$. hydrophila isolates from children with acute diarrhea found a high prevalence of resistance to several antibiotics, including bacitracin (95.2\%), novobiocin (95.2\%), vancomycin (90.5\%), cefazoline $(85.7 \%)$, methicillin $(85.7 \%)$, kanamycin $(81 \%)$, rifampicin $(76.2 \%)$, erythromycin $(71.4 \%)$, tetracycline $(71.4 \%)$, and nalidixic acid (62\%).55 Resistances found among 138 environmental aeromonads isolated from two European rivers included nalidixic acid (59\%), tetracycline (14\%), fosfomycin (8\%), tobramycin and cotrimoxazole $(7 \%)$, cefotaxime $(4 \%)$, chloramphenicol $(2 \%)$, and gentamicin (1\%). ${ }^{56}$ In another study, 217 clinical 
and non-clinical Aeromonas isolates were resistant to various antimicrobials, including clindamycin $(100 \%)$, vancomycin (100\%), erythromycin $(69.27 \%)$, cefazoline $(57.34 \%)$, sulfamethoxazole $(35.78 \%)$, rifampicin $(21.56 \%)$, and tetracycline $(9.63 \%) .{ }^{57}$ These results support the idea that a correlation exists between the prevalence of antibiotic resistance among aeromonads and the source of their isolation. Resistance to tetracyclines has been associated with plasmid-encoded genes ${ }^{51,58,59}$, and sulfonamide/ trimethoprim drug resistance has been associated with integrons60, confirming that Aeromonas is quite capable of acquiring antimicrobial resistance determinants from other groups of bacteria by lateral gene transfer. Quinolones and second- and thirdgeneration cephalosporins are generally considered to be the most effective antimicrobial agents against aeromonads in current clinical settings.

\section{RESULTS AND DISCUSSION}

The $A$. hydrophila recovered from the blood stream of Case 1 was resistant to ampicillin, ampicillin/ sulbactam, cefazolin, cefoxitin, and imipenem. This organism originated from the Pecos River, a different water source than for Case 2 and the playa lake study ${ }^{4}$ The $A$. hydrophila from the wound infection of Case 2 was resistant only to ampicillin. An A. hydrophila with similar biotyping and antibiotic sensitivities was recovered from the lake where the accident occurred.

Case 1 is representative of the many types of Aeromonas infections from freshwater exposure that have been reported previously. ${ }^{61-64}$ However, this patient was not immunosuppressed or ill prior to the acute burn injury. ${ }^{65}$ The early onset of the bacteremia and the lack of Aeromonas recovered from specimens other than the blood and the IV line tip led us to surmise that river water contaminated the IV line at the time of emergency placement. In contrast to the organism recovered from Case 1, the Aeromonas isolate from Case 2 was susceptible to multiple antimicrobial agents consistent with results obtained with the Aeromonas isolates from the two urban playa lakes. ${ }^{4}$

In summary, we report a case with bacteremia from an IV line placed under emergent circumstances in skin contaminated with river water and a case with a scalp wound from a laceration sustained in a local playa lake. Both infections occurred in immunocompetent individuals who acquired the $A$. hydrophila infections subsequent to trauma accompanied by direct exposure to freshwater environments. The infection contributed to a fatal outcome in the former patient, whereas the latter patient recovered completely. Infections due to Aeromonas species from freshwater sources have been previously reported. ${ }^{66}$ Most serious infections affect immunocompromised hosts. Aeromonas should be considered as a possible agent of infection from water exposure even if the water is a running river or a small, seemingly "clean" freshwater playa lake and should be considered in wounds with exposure to these waters in immunocompetent hosts.

Author Affiliation: Robert C. Kimbrough (deceased) and Richard E. Winn are in the Department of Internal Medicine, Division of Infectious Disease, Texas Tech University Health Sciences Center, Lubbock, TX. Randall M. Jeter, William J. Warren, Jennifer R. Huddleston, John C. Zak are in the Department of Biological Sciences, Texas Tech University, Lubbock, TX.

Received: 04/27/2016

Accepted: 09/07/2016

Reviewers: Edward Pesanti MD

Published electronically: 10/15/2016

Conflict of Interest Disclosures: None

\section{REFERENCES}

1. Hanson PG, Standridge J, Jarrett F, Maki DG. Freshwater wound infection due to Aeromonas hydrophila. J Am Med Assoc 1977; 238:1053-4.

2. Joseph SW, Daily OP, Hunt WS, Seidler RJ, Allen DA, Colwell RR. Aeromonas primary wound infection of a diver in polluted waters. J Clin Microbiol 1979; 10:46-9.

3. Pitlik S, Berger SA, Huminer D. Nonenteric infections acquired through contact with water. Rev Infect Dis 1987; 9:54-63.

4. Warren WJ, Jeter RM, Kimbrough RC, Zak JC. Population 
patterns and antimicrobial resistance of Aeromonas in urban playa lakes. Can J Microbiol 2004; 50:397-404.

5. Holt JG, Krieg NR, Sneath PHA, Staley JT, Williams ST. Bergey's Manual of Determinative Bacteriology, Ninth Edition. Philadelphia: Lippincott Williams \& Wilkins, 2000.

6. Martin-Carnahan A, Joseph SW. Family I. Aeromonadacae Colwell, MacDonell and De Ley 1986, 474VP. In: Brenner DJ, Krieg NR, Staley JT, eds. Bergey's Manual of Systematic Bacteriology, Second Edition, Volume 2 The Proteobacteria, Part B The Gammaproteobacteria. New York: Springer, 2005.

7. Presley SM, Rainwater TR, Austin GP, Platt SG, Zak JC, Cobb GP, Marsland EJ, Tian K, Zhang B, Anderson TA, Cox SB, Abel MT, Leftwich BD, Huddleston JR, Jeter RM, Kendall RJ. Assessment of pathogens and toxicants in New Orleans, LA following Hurricane Katrina. Environ Sci Technol 2006; 40:468-74.

8. Sharma A, Dubey N, Sharan B. Characterization of aeromonads isolated from the river Narmada, India. Int J Hyg Environ Health 2005; 208:425-33.

9. Villarruel-López A, Fernández-Rendón E, Mota-de-laGarza L, Ortigoza-Ferado J. Presence of Aeromonas spp. in water from drinking-water- and wastewater-treatment plants in México City. Water Environ Res 2005; 77:3074-9.

10. Vally H, Whittle A, Cameron S, Dowse GK, Watson T. Outbreak of Aeromonas hydrophila wound infections associated with mud football. Clin Infect Dis 2004; 38:1084-9.

11. Sen K, Rodgers M. Distribution of six virulence factors in Aeromonas species isolated from US drinking water utilities: a PCR identification. J Appl Microbiol 2004; 97:107786.

12. Villari P, Crispino M, Montuori P, Boccia S. Molecular typing of Aeromonas isolates in natural mineral waters. Appl Environ Microbiol 2003; 69:697-701.

13. Daskalov H. The importance of Aeromonas hydrophila in food safety. Food Control 2006; 17:474-83.

14. Isonhood JH, Drake M. Aeromonas species in foods. J Food Prot 2002; 65:575-82.

15. Kiebre-Toe MB, Lacheretz A, Villard L, Richard Y, Kodjo A. Pulsed-field gel electrophoresis profiles of aeromonads isolated from healthy and diseased Helix aspersa from French snail farms. Can J Microbiol 2005; 51:817-20.

16. Ottaviani D, Santarelli S, Bacchiocchi S, Masini L, Ghittino C, Bacchiocchi I. Occurrence and characterization of Aeromonas spp. in mussels from the Adriatic Sea. Food Microbiol 2006; 23:418-22.

17. Braschler TR, Merino S, Tomás JM, Graf J. Complement resistance is essential for colonization of the digestive tract of Hirudo medicinalis by Aeromonas strains. Appl Environ Microbiol 2003; 69:4268-71.

18. Graf J, Kikuchi Y, Rio RVM. Leeches and their microbiota: naturally simple symbiosis models. Trends Microbiol
2006; 14:365-71.

19. Worthen PL, Gode CJ, Graf J. Culture-independent characterization of the digestive-tract microbiota of the medicinal leech reveals a tripartite symbiosis. Appl Environ Microbiol 2006; 72:4775-81.

20. Vaseeharan B, Ramasamy P, Murugan T, Chen JC. In vitro susceptibility of antibiotics against Vibrio spp. and Aeromonas spp. isolated from Penaeus monodon hatcheries and ponds. Int J Antimicrob Agents 2005; 26:285-91.

21. Pidiyar V, Kaznowski A, Narayan NB, Patole M, Shouche YS. Aeromonas culicicola sp. nov., from the midgut of Culex quinquefasciatus. Int J Syst Evol Microbiol 2002; 52:1723-8.

22. Radu S, Ahmad N, Ling FH, Reezal A. Prevalence and resistance to antibiotics for Aeromonas species from retail fish in Malaysia. Int J Food Microbiol 2003; 81:261-6.

23. Huys G, Pearson M, Kämpfer P, Denys R, Cnockaert $\mathrm{M}$, Inglis V, Swings J. Aeromonas hydrophila subsp. ranae subsp. nov., isolated from septicaemic farmed frogs in Thailand. Int J Syst Evol Microbiol 2003; 53:885-91.

24. Jorge MT, Nishioka SA, Oliveira RB, Ribeiro LA, Silveira PVP. Aeromonas hydrophila soft-tissue infection as a complication of snake bite: report of three cases. Ann Trop Med Parasitol 1998; 92:213-7.

25. Turutoglu H, Ercelik S, Corlu M. Aeromonas hydrophila-associated skin lesions and septicaemia in a Nile crocodile (Crocodylus niloticus). J S Afr Vet Assoc 2005; 76:40-2. 26. Zbikowski A, Szeleszczuk P, Karpinska E, Rzewuska M, Malicka E, Binek M. Epidemic deaths of mallard ducks after Aeromonas hydrophila infection. Medycyna Wet 2006; 62:720-2. [Article in Polish].

27. Ghenghesh KS, Abeid SS, Jaber MM, Ben-Taher SA. Isolation and haemolytic activity of Aeromonas species from domestic dogs and cats. Comp Immunol Microbiol Infect Dis 1999; 22:175-9.

28. Kahn CM, Line S, eds. The Merck Veterinary Manual, Ninth Edition. Whitehouse Station, NJ: Merck \& Co., 2005. 29. Pasteris SE, Bühler MI, Nader-Macías ME. Microbiological and histological studies of farmed-bullfrog (Rana catesbeiana) tissues displaying red-leg syndrome. Aquaculture 2006; 251:11-8.

30. Figueras MJ. The clinical relevance of Aeromonas sM503. Rev. Med. Microbiol. 2005; 16:145-53.

31. Zhiyong Z, Xiaoju L, Yanyu G. Aeromonas hydrophila infection: clinical aspects and therapeutic options. Rev Med Microbiol 2002; 13:151-62.

32. Abbott SL. Aeromonas. In: Murray PR, Baron EJ, Jorgensen JH, Pfaller MA, Yolken RH, eds. Manual of Clinical Microbiology, Eighth Edition. Washington, DC: ASM Press, 2003; 701-5.

33. Janda JM, Abbott SL. Evolving concepts regarding the genus Aeromonas: an expanding panorama of species, dis- 
ease presentations, and unanswered questions. Clin Infect Dis 1998; 27:332-44.

34. Hua HT, Bollet C, Tercian S, Drancourt M, Raoult D. Aeromonas popoffii urinary tract infection. J Clin Microbiol 2004; 42:5427-8.

35. Vila J, Ruiz J, Gallardo F, Vargas M, Soler L, Figueras MJ, Gascon J. Aeromonas spp. and traveler's diarrhea: clinical features and antimicrobial resistance. Emerg Infect Dis 2003; 9:552-5.

36. Essers B, Burnens AP, Lanfranchini FM, Somaruga SGE, von Vigier RO, Schaad UB, Aebi C, Bianchetti MG. Acute community-acquired diarrhea requiring hospital admission in Swiss children. Clin Infect Dis 2000; 30:192-6.

37. Filler G, Ehrich JHH, Strauch E, Beutin L. Acute renal failure in an infant associated with cytotoxic Aeromonas sobria isolated from patient's stool and from aquarium water as suspected source of infection. J Clin Microbiol 2000; 38:469-70.

38. Juan H-J, Tang R-B, Wu T-C, Yu K-W. Isolation of Aeromonas hydrophila in children with diarrhea. J Microbiol Immunol Infect 2000; 33:115-7.

39. Robles-Medranda C, Lukashok HP, Novais P, Biccas B, Fogaça H. Chronic diarrhea as first manifestation of liver cirrhosis and hepatocarcinoma in a teenager: a case report and review of the literature. J Pediatr Gastroenterol Nutr 2006; 42:434-6.

40. Taneja N, Khurana S, Trehan A, Marwaha RK, Sharma M. An outbreak of hospital acquired diarrhea due to Aeromonas sobria. Indian Pediatr 2004; 41:912-916.

41. Teka T, Faruque ASG, Hossain MI, Fuchs GJ. Aeromonas-associated diarrhoea in Bangladeshi children: clinical and epidemiological characteristics. Ann Trop Paediatr 1999; 19:15-20.

42. Chu YW, Wong CH, Tsang GKL, Kwok MSW, Wong RKO, Lo JYC, Kam KM. Lack of association between presentation of diarrhoeal symptoms and faecal isolation of Aeromonas spp. amongst patients in Hong Kong. J Med Microbiol 2006; 55:349-51.

43. Millership SE, Curnow SR, Chattopadhyay B. Faecal carriage rate of Aeromonas hydrophila. J Clin Pathol 1983; 36:920-3.

44. Pitarangsi C, Echeverria $P$, Whitmire R, Tirapat C, Formal S, Dammin GJ, Tingtalapong M. Enteropathogenicity of Aeromonas hydrophila and Plesiomonas shigelloides: prevalence among individuals with and without diarrhea in Thailand. Infect Immun 1982; 35:666-73.

45. Ardehali B, Hand K, Nduka C, Holmes A, Wood S. Delayed leech-borne infection with Aeromonas hydrophila in escharotic flap wound. J Plast Reconstr Aesth Surg 2006; 59:94-5.

46. Fenollar F, Fournier PE, Legre R. Unusual case of Aeromonas sobria cellulitis associated with the use of leech- es. Eur J Clin Microbiol Infect Dis 1999; 18:72-73.

47. Sartor C, Limouzin-Perotti F, Legré R, Casanova D, Bongrand M-C, Sambuc R, Drancourt M. Nosocomial infections with Aeromonas hydrophila from leeches. Clin Infect Dis 2002; 35:e1-5.

48. Hiransuthikul N, Tantisiriwat W, Lertutsahakul K, Vibhagool A, Boonma P. Skin and soft-tissue infections among tsunami survivors in southern Thailand. Clin Infect Dis 2005; 41:e93-6.

49. Abbott SL, Cheung WKW, Janda JM. The genus Aeromonas: biochemical characteristics, atypical reactions, and phenotypic identification schemes. J Clin Microbiol 2003; 41:2348-57.

50. Huddleston JR, Zak JC, Jeter RM. Sampling bias created by ampicillin in isolation media for Aeromonas. Can J Microbiol 2007; 53:39-44.

51. Palú AP, Gomes LM, Miguel MAL, Balassiano IT, Queiroz MLP, Freitas-Almeida AC, Oliveira SS. Antimicrobial resistance in food and clinical Aeromonas isolates. Food Microbiol 2006; 23:504-9.

52. Fosse T, Giraud-Morin C, Madinier I, Mantoux F, Lacour JP, Ortonne JP. Aeromonas hydrophila with plasmid-borne class A extended-spectrum $\beta$-lactamase TEM-24 and three chromosomal class $\mathrm{B}, \mathrm{C}$, and $\mathrm{D} \beta$-lactamases, isolated from a patient with necrotizing fasciitis. Antimicrob Agents Chemother 2004; 48:2342-3.

53. Walsh TR, Stunt RA, Nabi JA, MacGowan AP, Bennett PM. Distribution and expression of $\beta$-lactamase genes among Aeromonas spp. J Antimicrob Chemother 1997; 40:171-8.

54. Marchandin H, Godreuil S, Darbas H, Jean-Pierre H, Jumas-Bilak E, Chanal C, Bonnet R. Extended-spectrum $\beta$-lactamase TEM-24 in an Aeromonas clinical strain: acquisition from the prevalent Enterobacter aerogenes clone in France. Antimicrob Agents Chemother 2003; 47:3994-5.

55. Subashkumar R, Thayumanavan T, Vivekanandhan G, Lakshmanaperumalsamy P. Occurrence of Aeromonas hydrophila in acute gasteroenteritis among children. Indian $\mathbf{J}$ Med Res 2006; 123:61-6.

56. Goñi-Urriza M, Pineau L, Capdepuy M, Roques C, Caumette P, Quentin C. Antimicrobial resistance of mesophilic Aeromonas spp. isolated from two European rivers. J Antimicrob Chemother 2000; 46:297-301.

57. Kämpfer $P$, Christmann $C$, Swings J, Huys G. In vitro susceptibilities of Aeromonas genomic species to 69 antimicrobial agents. Syst Appl Microbiol 1999; 22:662-9.

58. Majumdar T, Ghosh S, Pal J, Mazumder S. Possible role of a plasmid in the pathogenesis of a fish disease caused by Aeromonas hydrophila. Aquaculture 2006; 256:95-104.

59. Rhodes G, Huys G, Swings J, McGann P, Hiney M, Smith P, Pickup RW. Distribution of oxytetracycline resistance plasmids between aeromonads in hospital and aquaculture environments: implication of Tn1721 in dissemination of the 
tetracycline resistance determinant Tet A. Appl Environ Microbiol 2000; 66:3883-90.

60. Schmidt AS, Brunn MS, Dalsgaard I, Larsen JL. Incidence, distribution, and spread of tetracycline resistance determinants and integron-associated antibiotic resistance genes among motile aeromonads from a fish farming environment. Appl Environ Microbiol 2001; 67:5675-82.

61. Baddour LM. Extraintestinal Aeromonas infectionslooking for Mr. Sandbar. Mayo Clin Proc 1992; 67:496-8.

62. Ko W-C, Lee H-C, Chuang Y-C, Liu C-C, Wu J-J. Clinical features and therapeutic

implications of 104 episodes of monomicrobial Aeromonas bacteraemia. J Infect 2000;

40:267-73.

63. Murphey DK, Septimus EJ, Waagner DC. Catfish-related injury and infection: report of two cases and review of the literature. Clin Infect Dis 1992; 14:689-93.

64. Voss LM, K. Rhodes KH, Johnson KA. Musculoskeletaland soft tissue Aeromonas infection: an environmental disease. Mayo Clin Proc 1992; 67:422-7.

65. Wolff RL, Wiseman SL, Kitchens CS. Aeromonas hydrophila bacteremia in ambulatory immunocompromised hosts. Am J Med 1980; 68:238-42.

66. Auerbach PS, Yajko DM, Nassos PS, Kizer KW, Morris Jr JA, Hadley WK. Bacteriology of the freshwater environment: implications for clinical therapy. Ann Emerg Med 1987; 16:1016-22. 